\title{
An Integration of Methodological Resources into Learning Object Metadata Repository
}

\author{
Valentina DAGIENĖ, Tatjana JEVSIKOVA, Svetlana KUBILINSKIENE் \\ Vilnius University Institute of Mathematics and Informatics \\ Akademijos 4, LT-08663 Vilnius, Lithuania \\ e-mail:valentina.dagiene@mii.vu.lt, tatjana.jevsikova@mii.vu.lt, \\ svetlana.kubilinskiene@mii.vu.lt
}

Received: June 2011; accepted: October 2012

\begin{abstract}
The number of digital resources to be used and reused for learning (learning objects) is constantly increasing, therefore describing learning objects with metadata is important to enhance learning object search, retrieval, and usage. Learning objects can be considered not only as resources, providing learning content, but as methodological resources, including teachers' experiences, reflections, examples or instructions of usage of content objects, and descriptions of learning methods. However, existing standards and specifications for learning objects metadata are not intended for including methodological resources and learning method descriptions together with content objects. In this paper, we present the results of a study, carried among general school teachers, which present a view of teachers on methodological resources and their importance, and propose a new model of learning object metadata for the learning object repository to include methodological resources, descriptions of learning methods and their links with content objects.
\end{abstract}

Keywords: learning object, learning object metadata, learning object metadata repository, methodological learning resources, learning activities, learning methods, learning object metadata repository model.

\section{Introduction}

In past decade a lot of efforts have been put into development of e-learning: many systems have been developed, a notion of learning object (LO) has been introduced and spread around, repositories of learning objects have been developed, learning object metadata standards have been released, interoperability of e-learning system components have been discussed.

There is a great variety of learning object definitions in research literature. One of the mostly cited definitions is "LO is any digital resource that can be reused to support learning" (Wiley, 2000). The key notion here is "reusability". However, digital learning resources by themselves are not so valuable as their purposive application in the learning process as well as a properly selected learning method, therefore in order to find them metadata are indispensable. The systematically prepared metadata help all the parties, involved in learning process, to cooperate, use and share learning resources. 


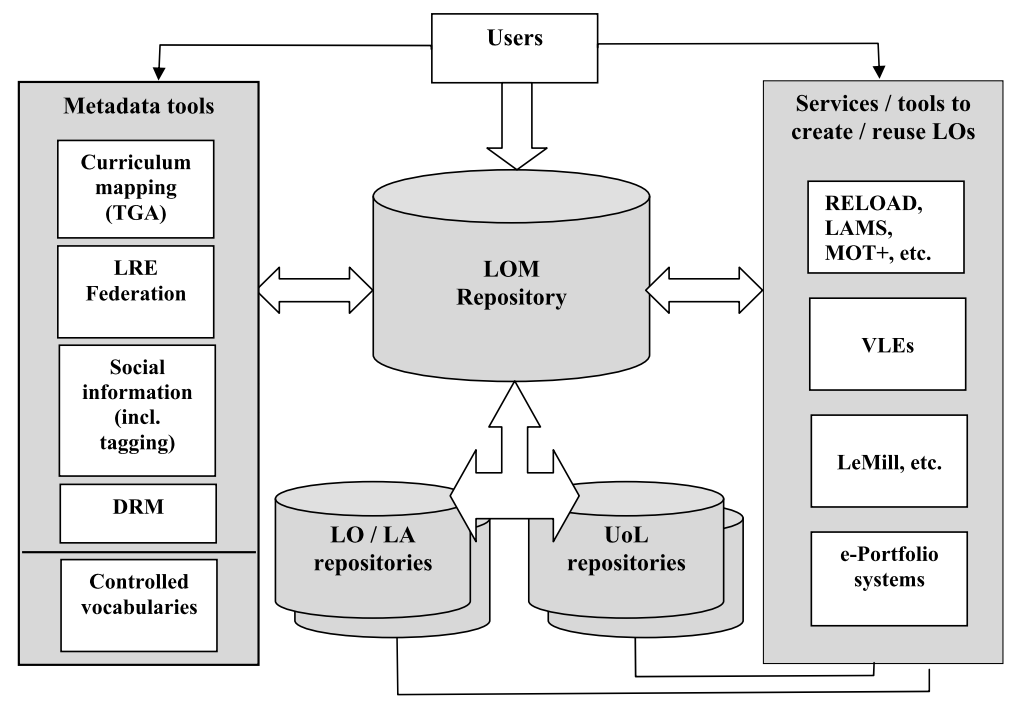

Fig. 1. The scheme of DLE components.

Sharing resources and services is possible only if all the parts concerned have followed a clear agreement to the rules. The larger the scope of agreement, the larger the benefit. It can be realized in practice in case there exists interoperability between such different areas as the learning content and learning activity, accessibility, assessment, management and information to the learners. Various standards and specifications are used to implement these agreements. This paper deals only with the following interoperability aspects of learning content and learning activities: (1) description of the content and use; (2) development of materials related to interoperability issues.

The Lithuanian LO metadata repository was developed during the participation in several European projects (e.g., Calibrate ${ }^{1}$, Aspect ${ }^{2}$ ), therefore, it reflects international tendencies.

The repository is a part of a national educational portal and brings together LO metadata for Lithuanian education. The LO metadata repository is an essential part of the national Digital Library of Educational resources and services (DLE). DLE scheme, based on a flexible, modular architecture and free and open source, reusable e-content and eservices components, is presented in Fig. 1 (Kurilovas and Kubilinskiené, 2008).

LO should be considered as a resource, providing (reusable) learning or teaching content. Modern student-centered methodology requires involving learner into his or her active knowledge construction, applying a wide range of active learning methods, reflecting, sharing teachers' experience, etc. (Turcsanyi-Szabo, 2012). To help this happen, the teachers should be able to find (and publish) not only learning resources, providing learn-

\footnotetext{
${ }^{1}$ European Schoolnet. Calibrate: Learning Resources for Schools, http: / / calibrate. eun.org/merlin/index.cfm.

${ }^{2}$ ASPECT. Adopting Standards and Specifications for Educational Content, http: / /www . aspect-project. org/node/ 40 .
} 


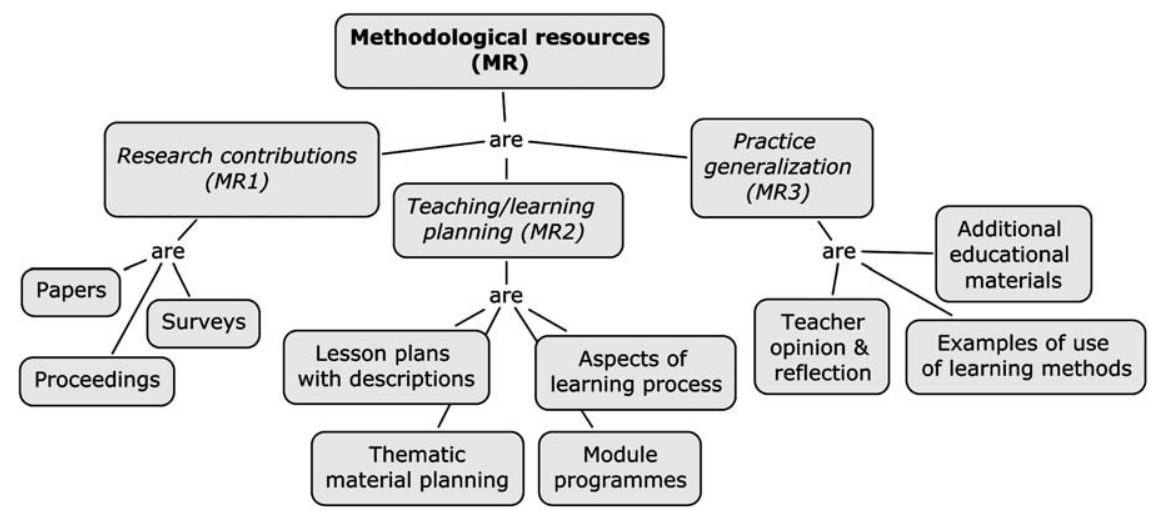

Fig. 2. A structure of methodological resources.

ing content for their students, but a wide spectrum of methodological materials as well that help them to make teaching process more effective.

Our suggestion is to divide LO into several large groups according to their purpose:

1. Content LOs. These LOs help students to reach the learning goals. Usually, it is a learning material for some subject or topic.

2. Methodological resources (MR) provide pedagogical experience, usually addressed to other teachers, as well as descriptions, how content and learning methods LOs are used in teaching and learning processes (Fig. 2). Usually, they can be research contributions (MR1) (e.g., methodological papers, surveys, and methodological conference proceedings), teaching/learning planning resources (MR2) (e.g., lesson plans, thematic material planning, programmes of some teaching or learning modules, and aspects of learning process), practice generalization resources (MR3) (teacher reflections and opinions, additional educational materials, and use of teaching/learning methods).

3. Learning methods (LM). These LOs enable to organize learning processes. Usually, they are represented by descriptions of LM. Methodological resources, in turn, describe how to use learning methods (which can be described via learning methods LOs) for teaching and learning.

A lot of MR has been created or is under development for traditional lessons at Lithuanian schools by using information and communication technologies (ICT) in order that students better understand the matter and develop their capabilities: to demonstrate the new material, to do laboratory works as well as individual or team work, testing, selfcontrol and other activities. Methodological resources, in which information is presented how ICTs and learning resources are used in class or in after-class activities and which teaching methods teachers apply in lesson, make up a huge resource of accumulated pedagogical experience that can be shared. The key purpose of methodological resources is to render conditions for teachers to share the professional experience, to spread methodological novelties, to help students and their parents to join the training and learning process more actively. A free way of choosing learning methods obligates teachers to know and 
estimate them first of all, in line with the requirements posed to the contemporary school.

However, existing standards and specifications for learning objects metadata are not intended for including methodological resources and learning method descriptions together with content objects (see Section 2). The National LO metadata repository, created in Lithuania, is based on the LRE LOM AP v3.0 standard. However, the search present in it does not allow us to find desirable methodological resources and learning method objects, because the repository possibilities are insufficient to describe them explicitly. The same problem is valid for any other LO metadata repository, using existing LO metadata standards.

Existing Lithuanian practice to create methodological materials is mostly based on the template, used in the initiative "Virtual Classroom Tour" under the Microsoft programme "Partners in Learning"3. The target groups of the project are teachers of general education and vocational training schools. The model of "Virtual Classroom Tour" is based on the understanding that learning from the one another experience is an effective way of school development. These MR are stored in a separate online repository ${ }^{4}$.

The template of the methodological material of "Virtual Classroom Tour" is made of five slides which should be filled in and linked with additional documents by the teachers:

- An overview of a lesson, sequence of lessons or a project (subject, students' age, goals, short description; software used, keywords, authors as well as a list of used literature).

- The context and a plan of a lesson, lesson cycle or a project, as well images of the implementation in the classroom.

- Learning materials for students, used in the project (e.g., assignments overview, content LOs, materials from the Internet or other sources, instructions).

- Description of the curriculum goals set in the project, details on the students' assessment, and a reflection of a teacher.

- Teacher's contacts.

An analysis of various LOs, described in European and Lithuanian LO metadata repositories (Kubilinskienè and Dagienè, 2010) has revealed these findings:

1. There are specialized sites, publishing learning objects of MR1 type. Unfortunately, they are not enriched with extensive metadata to be available for search and comfortable educational use. Sometimes, access to methodological conference proceedings is denied after the conference had been held.

2. Inside some methodological resources of MR2 type (especially, lesson plans), there is a lot of meta information, i.e., data to be used to find these LOs. To be available for LO search, this information is sometimes duplicated, otherwise it is not extracted and is "hidden" inside the LO, and the search can not benefit from it.

3. In the vast majority of MR2 (especially, lesson plans), there are descriptions and/or links to the appropriate content LOs. These content LOs are "hidden" inside the methodological LOs, and therefore, the use of these content LOs is reduced.

\footnotetext{
${ }^{3}$ Microsoft Corporation. Partners in Learning,

http: / /www.microsoft.com/lietuva/education/pil/ (in Lithuanian).

${ }^{4}$ Virtual Classroom Tour Repository,

http: //metodika.emokykla. lt/sites/vkk/default.aspx (in Lithuanian).
} 
4. There is a great variety of MR2 type LOs and their representations. Therefore, it is difficult to automate their metadata generation.

5. There are very few learning method objects available in repositories.

To better understand the current situation, regarding LO metadata repository, and to find a way to make it more convenient to publish/find methodological resources and learning methods, together with content LOs, we have performed a study among teachers (Section 3). The survey is conducted among Lithuanian teachers, but it reflects common problems of methodological resources accessibility and inclusion into learning resource metadata repository, and therefore we hope that the results, presented in this paper, are useful not only in Lithuania, but for an international audience as well. In Section 4 we propose a model of LO metadata to include methodological resources and learning methods descriptions into LO metadata repository.

\section{LO Description in a Formal Way: An Analysis of LO Metadata Models}

Metadata is the most important part of the information management infrastructure in data repositories. The metadata is defined according to the standards, specifications or their application profiles (AP). In this section, four main existing models of learning object metadata standards are analyzed in the view of their elements: Learning Object Metadata (LOM), Dublin Core (DC), Machine-Readable Cataloging (MARC21) and UNIMARC. The analysis of these standards from the aspect of their purpose is presented in paper Kubilinskienè and Dagienè (2010). The main objective of these standards is to facilitate LO search, acquisition and use as well as to simplify sharing the teaching and learning objects, taking into consideration a variety of cultural and linguistic contexts.

A comparison of standards elements is presented in Table 1.

Our comparison and the survey of examples of metadata standard application in practice (e.g., Barbosa et al., 2003) has shown that Dublin Core, MARC21 and UNIMARC metadata standard models suite quite well to describe the bibliographic part of digital resource, while the pedagogical issues can be described only partly. The IEEE LOM (Learning Object Metadata) standard (IEEE, 2002) allows the best metadata description of pedagogical issues of learning resources, and is most suitable to include descriptions of methodological resources and learning methods. Flexibility of the IEEE LOM model allows us to develop new application profiles. The IEEE LOM model has quite a lot of educational application profiles (Steinacker et al., 2001; McClelland, 2003), what lets us make an assumption that LOM model is widely used in educational area and can help us to reflect the main properties of methodological resources and learning methods.

\section{A Study on Usage of Methodological Learning Resources by Teachers}

In order to find out teachers' opinions on services of learning object metadata repository of the Lithuanian educational portal, a study was conducted in autumn, 2010. 
Table 1

Comparison of metadata standards' elements

\begin{tabular}{|c|c|c|c|c|}
\hline Elements & LOM & $\mathrm{DC}$ & MARC21 & UNIMARC \\
\hline Title & General.Title (1.2) & DC.Title & 245 & $200 \$ a$ \\
\hline $\begin{array}{l}\text { Language of LO } \\
\text { content }\end{array}$ & General.Language (1.3) & DC.Language & $\begin{array}{l}008 / 35-37 \\
546\end{array}$ & 101 \\
\hline $\begin{array}{l}\text { Textual description } \\
\text { of the content of LO }\end{array}$ & General.Description (1.4) & DC.Description & $\begin{array}{l}500-559 \\
\text { except } \\
506,530,540, \\
546\end{array}$ & - \\
\hline $\begin{array}{l}\text { A keyword describing } \\
\text { the topic of LO }\end{array}$ & General.Keyword (1.5) & DC.Subject & $\begin{array}{l}600,610,611 \\
630,650,653\end{array}$ & 606 \\
\hline $\begin{array}{l}\text { The time, culture, } \\
\text { region to which } \\
\text { this LO applies }\end{array}$ & General.Coverage (1.6) & DC.Coverage & 651,752 & - \\
\hline $\begin{array}{l}\text { Entities that have } \\
\text { contributed to LO } \\
\text { creating, editing, }\end{array}$ & $\begin{array}{l}\text { LifeCycle.Contribute. } \\
\text { Entity (2.3.2) }\end{array}$ & DC.Creator & $\begin{array}{l}100,110,111, \\
700,710,711, \\
720\end{array}$ & 700,710 \\
\hline publishing & & $\begin{array}{l}\text { DC.Publisher } \\
\text { DC.Contributor }\end{array}$ & $260 \$ a \$ b$ & $\begin{array}{l}210 \$ c \\
-\end{array}$ \\
\hline Data of publishing & $\begin{array}{l}\text { LifeCycle.Contribute. } \\
\text { Date (2.3.3) as } \\
\text { LifeCycle.Contribute. } \\
\text { role = Publisher }\end{array}$ & DC.Date & $260 \$ c$ & $210 \$ d$ \\
\hline Issue of LO & $\begin{array}{l}\text { LifeCycle. } \\
\text { Version }(2.1)\end{array}$ & - & - & $205 \$ a$ \\
\hline $\begin{array}{l}\text { Technical data type(s) } \\
\text { of LO }\end{array}$ & Technical.Format (4.1) & DC.Format & $856 \$ q$ & 215 \\
\hline The size of LO in bytes & Technical.Size (4.2) & & & \\
\hline Location of LO & Technical.Location (4.3) & & $856 \$ \mathrm{u}$ & 001 \\
\hline $\begin{array}{l}\text { Learning Resource } \\
\text { Type }\end{array}$ & $\begin{array}{l}\text { Educational.Learning } \\
\text { ResourceType (5.2) }\end{array}$ & DC.Type & 655 & - \\
\hline Intended end user role & $\begin{array}{l}\text { Educational.Intended } \\
\text { EndUserRole (5.5) }\end{array}$ & DC.Audience & - & - \\
\hline Context & Educational.Context (5.6) & & - & - \\
\hline $\begin{array}{l}\text { Age of the typical } \\
\text { intended user }\end{array}$ & $\begin{array}{l}\text { Educational.Typical } \\
\text { AgeRange ( } 5.7)\end{array}$ & & - & - \\
\hline $\begin{array}{l}\text { Description of the copy- } \\
\text { right and other } \\
\text { restrictions }\end{array}$ & Rights.Description (6.3) & DC.Rights & 506 & - \\
\hline $\begin{array}{l}\text { Resource of which the } \\
\text { described resource was } \\
\text { derived }\end{array}$ & $\begin{array}{l}\text { Relation.Resource as } \\
\text { Relation.Kind }= \\
\text { IsBasedOn } \\
(7.1 ; 7.2)\end{array}$ & DC.Source & $786 \$ o \$ t$ & 010,011 \\
\hline $\begin{array}{l}\text { Description of the } \\
\text { related resource }\end{array}$ & $\begin{array}{l}\text { Relation.Resource. } \\
\text { Description (7.2.2) }\end{array}$ & DC.Relation & $530,760-787 \$ o \$ t$ & \\
\hline $\begin{array}{l}\text { The topic of LO } \\
\text { content }\end{array}$ & Classification $(9.1 ; 9.4)$ & DC.Subject & $\begin{array}{l}600,610,611 \\
630,650,653\end{array}$ & 606 \\
\hline
\end{tabular}


The teachers got a questionnaire, consisting of three main parts. The first part was intended to find out the background of the teachers (contact data, school, grades and subjects they teach, overall ICT level of the school). The second part of the questionnaire aimed to evaluate teachers' practical experience of using digital learning resources (i.e., which resources they use during preparation for the lessons, which types of learning resources they use in the classroom, whether they prepare lesson plans, which teaching, learning, and assessment methods they use, how they search for digital learning resources). The third part of the questionnaire was used to evaluate the quality of the services of the repository and the appropriateness of its content. In this paper, we present only those results that are related to LO metadata model development.

Unless the study, presented in this paper, is local and is aimed to evaluate local LO metadata repository, it reflects general tendencies and may be valuable for metadata models development in general.

\subsection{The Respondents}

There were 49 respondents, chosen throughout the country from primary, lower and upper secondary schools, teaching various subjects (the majority are information technology teachers, others teach science, mathematics, languages, history, arts and design, primary education and other subjects). 48.9\% of respondents were so called 'ICT leaders' (experienced teachers and advanced ICT users), teaching various subjects. The name 'ICT leader' came from the project, organized by the Ministry of Education and Science of Lithuania and the Microsoft Corporation, which aims to identify active teachers and develop their competences to become leaders in using ICT in education, spread their practice and help other teachers to efficiently use ICT in their work.

$51 \%$ of respondents have been working as school teachers for 10 to 20 years, $35 \%$ of the respondents have been teaching for more than 20 years, $8 \%$ have been teaching for 5 to 10 years, and $6 \%$ of respondents have teaching experience of less than 5 years. The vast majority of the ICT leaders have been working at a school for 10 to 20 or even more than 20 years (Fig. 3).

All the respondents came from schools that had internet connection, one or more computers for teacher use, computer laboratories, projector(s) or interactive whiteboard(s) in some classrooms. Fewer schools had one or more computers in subject classrooms, a computer for every teacher, multimedia projectors in all or almost all classrooms, interactive whiteboards in subject classrooms. This means that all respondents' schools have at least minimal or average technological environment and prerequisites to actively use digital learning resources.

\subsection{Using Digital and Non-Digital Learning Resources and Methods in Teaching and Learning Process}

Practically all the teachers, participating in the study, consider using digital learning resources to be a useful practice to enhance students' knowledge (82\%), skills (88\%), and learning motivation (90\%). 


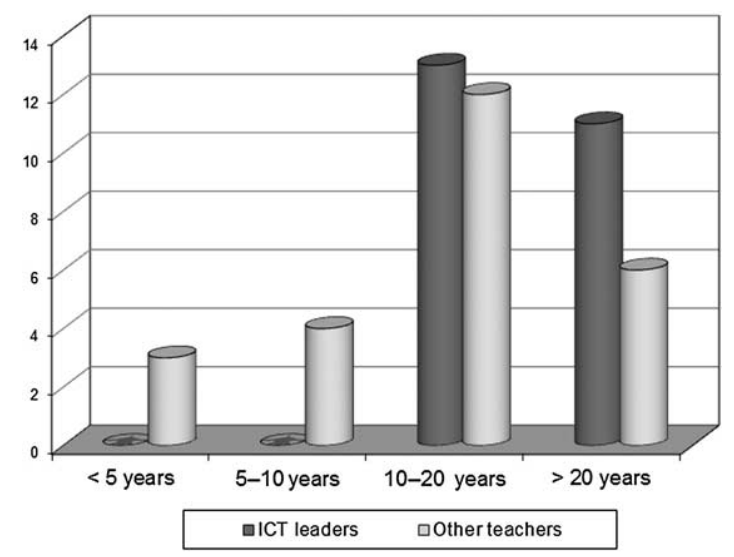

Fig. 3. Respondents' teaching experience in comprehensive schools.

Before looking at the quality of existing learning resources, we wanted to identify, to what extend teachers use learning resources for teaching. The results have shown that teachers use:

- Every day: personal notes (76\%), textbooks (77\%), lesson plans (62\%), selfdeveloped digital content (56\%).

- Every week: drill and practice workbooks (39\%), books for teachers (35\%), professional literature (42\%), digital learning resources on CDs or DVDs (50\%), and digital learning resources from national/regional repository $(35 \%)$.

- Every month: conference proceedings or methodological papers (53\%), materials, describing practices of other teachers (40\%), descriptions of learning methods $(36 \%)$. The majority of positive answers to this point were given by ICT leaders.

- Every half a year: conference proceedings or methodological papers (31\%), covering practices of other teachers (32\%), and descriptions of learning methods (42\%).

Comparing the answers of ICT leaders with those of other teachers, we can notice that ICT leaders use more and more often:

- Conference proceedings and methodological papers;

- Learning methods descriptions;

- Self-developed learning resources.

The reason of this can be the higher competency of ICT leaders in their teaching subject and ICT usage in teaching and learning process.

Assumption 1. By describing all the methodological resources and tools mentioned above with metadata and making them more accessible we can raise the competence of the teachers.

Lesson plans make up an important part of methodological resources, and help teachers ensure the quality of educational process. $31 \%$ of respondents download and use lesson plans from the internet. 56\% of respondents prepare new lesson plans every year. 


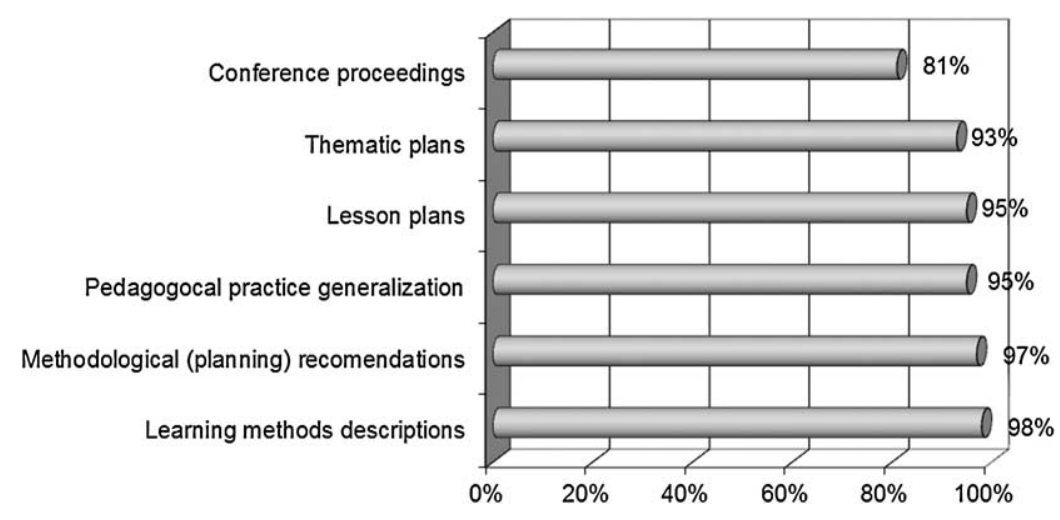

Fig. 4. Influence of the lack of methodological materials to the usage of content learning objects.

In Lithuania, lesson plans are usually prepared using "Virtual Classroom Tour" template, shortly described in Section 1.

The study has shown that $21 \%$ of teachers doubt that "Virtual Classroom Tour" template lets to prepare detailed and well-structured lesson plan. $22 \%$ doubted that this template is suitable to provide lesson plan metadata. 33\% of participants doubted that the template is convenient to find content LOs, used in the lesson plan, and find lesson plans by the learning methods used in it. $15 \%$ of teachers totally disagreed that the template is convenient to find a lesson plan by the learning method described inside it. The answers of ICT leaders and regular teachers did not have any significant difference.

Assumption 2. Enhanced lesson plan technology-based template will help to increase the lesson plan sharing experience.

Most of the teachers agree that usage of content learning objects is influenced by the lack of descriptions of learning methods and methodological materials (generalization of pedagogical practice, thematic or lesson plans, and planning recommendations; Fig. 4). The answers of ICT leaders and other teachers did not have significant difference.

Assumption 3. Extended metadata model will enable to describe learning methods, methodological resources, and in this way increase the usage of content learning objects.

Assumption 4. The implementation of the model will increase the access to the learning methods resources and will introduce users to modern learning methods and examples of their applications.

As we can notice from the Fig. 4, the teachers think there is lack of descriptions of learning methods. So, it is important to know, which learning methods teachers use in their everyday practice and how often.

Most of teachers (more than $50 \%$ of the respondents) use instruction, individual assignments, questions (inquiry), teacher's presentation, assignments in groups and pairs, and various activities every week. Every half a year most of the teachers use project works (however, this do not let us understand, either there are a long-time projects, or rare short-time projects). 


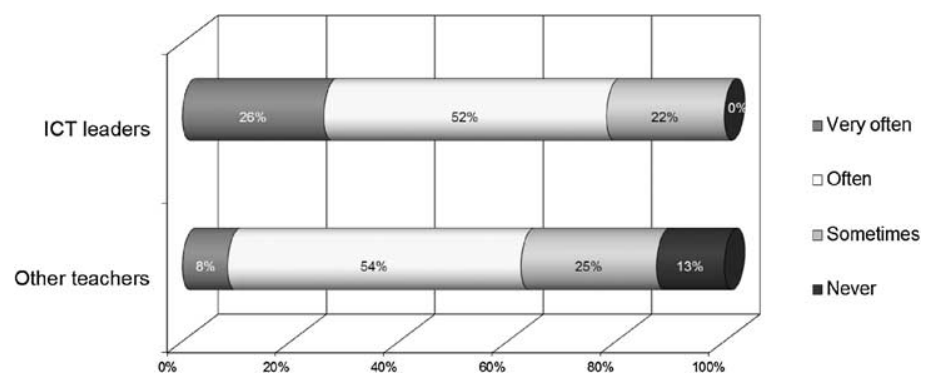

Fig. 5. Comparison of "brain storming" activity usage frequency.

Teachers still rarely use so called active methods and activities, as collaboration, students' presentations, brain storming, concept maps etc. However, the difference between ICT leaders and other teachers is significant. ICT leaders more often use active methods, requiring more activity from students than classical methods. As an example, the results for "brain storming" activity are presented in Fig. 5.

Probably, not sufficient use of active methods is caused by the lack of methodological materials on how to use these methods in the classroom, as well as learning methods descriptions, as we could see from previous results.

Let us see more differences in methods usage between ICT leaders and other teachers:

- ICT leaders use in their lessons assignments in groups and assignments in pairs every week, other teachers use only every month.

- Projects more often are used by ICT leaders (every month).

- Collaboration methods are most often used by ICT leaders (every month), while it is less frequent in other teachers' practice.

- Various activities (brain storming, aquarium, etc.) are most used by ICT leaders (every week), while other teachers use them more rarely or do not use at all.

- ICT leaders use reading methods (text marking, etc.) every week, while $20 \%$ of other teachers do not use these methods at all.

In order to know, what type of classification of learning methods it is better to use in learning method description, relating them to the appropriate methodological materials, teachers were presented several classification alternatives.

- By information presentation type (e.g., verbal, visual). This classification type was supported by $74 \%$ of teachers.

- By the ratio between theory and practice (e.g., theoretical, practical). This alternative was supported by the $76 \%$ of teachers.

- By the level of teacher or student activity (e.g., active, passive). This classification type was supported by the $65 \%$ of teachers.

- Authoritarian/humanistic methods (e.g., curricula-oriented or student-oriented). $50 \%$ of teachers agreed or partly agreed with this classification method.

- By the creativity level of learning activity (e.g., reproductive, creative). $78 \%$ of teachers agreed with this classification.

- By the student's reasoning operations (e.g., analysis, synthesis, hypothesis, deduction, induction). $65 \%$ of teachers agreed with this classification. 
- By the student's activity (e.g., reading, writing, inquiry, collaboration). $82 \%$ supported this classification.

- Using classical teaching methods classification (e.g., information, practical, operational, creative). This variant was supported by the $80 \%$ of teachers.

The answers of ICT leaders did not differ from the answers of other teachers.

So, we can see that teachers support various classification types.

Assumption 5. The relation of methodological resources to learning methods should be as flexible as possible, using various classification criteria.

Regarding LO search preferences, we have got such results:

- $88 \%$ of teachers totally agree or agree that it is comfortable to search learning objects on a single website.

- The idea that it is comfortable to search for learning activities scenarios and lesson plans by learning method used, was supported by $41 \%$ of teachers.

- $23 \%$ of teachers totally agree or agree that it is comfortable to conduct search of learning objects in European LO repositories. 38\% almost agreed with this proposition, $33 \%$ of teachers disagreed, and $6 \%$ did not know. Such a difference in responses can be explained by not usual practice of search and use of LOs from European repositories by teachers. There are not enough methodological materials on usage of such LOs available.

- $82 \%$ of teachers stated that they totally agree or agree that it is convenient to create and share lesson plans in a single specialized site.

The answers of ICT leaders did not differ from the answers of other teachers.

We can make a conclusion that: (a) teachers prefer to look for learning resources in a single place, not in distributed LO repositories of various vendors; and (b) teachers would like to describe and share lesson plans in a single specialized website; (c) with growing experience, teachers probably would like to search for LOs in the European LO repositories; (d) with growing experience, teachers probably would like to search for scenarios of learning activities and lesson plans by the learning methods used.

\subsection{The Quality of Services and Resources of the Educational Portal Learning Object Metadata Repository}

The third part of the questionnaire was intended to study the opinions of the teachers regarding the quality of services and resources of the Educational Portal Learning Object Metadata Repository (EPLOMR).

Figure 6 presents the opinion of teachers on the overall quality of the learning resources, described in the Educational portal learning object metadata repository.

As we can see on Fig. 6, 6\% of teachers think that the resources are of very high quality, $29 \%$ consider the resources are of high quality, $61 \%$ think that the resources are of moderate quality. Only $4 \%$ think that the resources are of low quality, and nobody thinks that the quality of the resources is very low.

$98 \%$ of all teachers think that the content, provided by the digital learning resources metadata repository, is useful. 


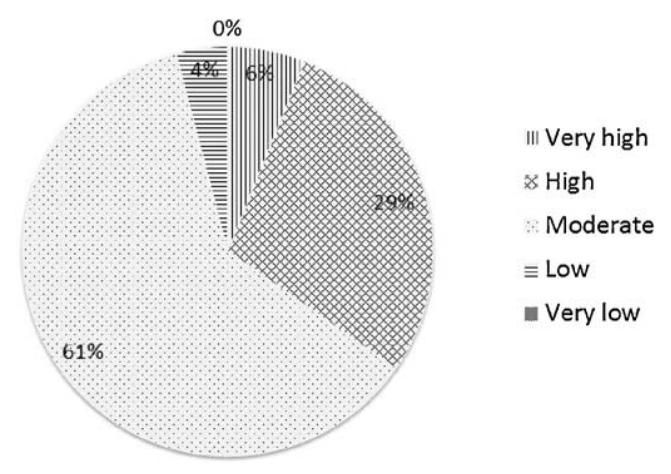

Fig. 6. The evaluation of the overall quality of the learning resources, described in the LO repository.

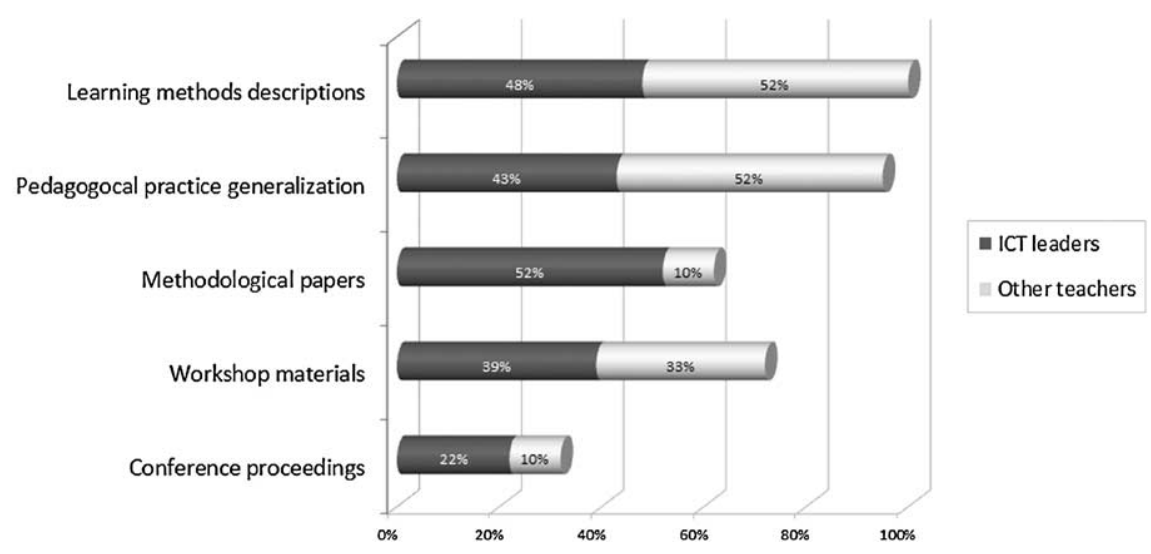

Fig. 7. What type of resources metadata teachers lack for the LO metadata repository.

In order to improve the quality of LO metadata repository services, we should learn, what types of information or learning resources teachers prefer to find in the repository. The teachers mostly feel the lack of the descriptions of learning methods (50\%). $48 \%$ of teachers think that there are not enough of materials, describing experience of other teachers. 32\% lack methodological papers, $36 \%$ and $16 \%$ respectively think that there are not enough seminar (workshop) materials and conference proceedings.

The answers of ICT leaders, comparing with those of other teachers (Fig. 7), reveal that more ICT leaders lack for methodological papers and conference proceedings than other teachers. Other responses were similar.

The study has revealed that $50 \%$ of the teachers agree that there are not enough links between content LOs and methodological materials. $49 \%$ of teachers totally agree and agree that there are not enough links between methodological materials and learning methods.

Assumption 6. By implementing links in LO metadata repository between methodological materials and learning methods, as well as content LOs and appropriate methodological material, we can improve the LO search efficiency and accuracy. 
Based on the obtained results, we formulate a hypothesis that the extended metadata model will enable us describe methodological resources and teaching method objects in the LO metadata repository and will establish conditions:

- to improve accessibility to methodological and teaching method resources, which will result in acquaintance with modern learning methods and their application examples;

- to increase the content LO use;

- to create lesson plans, using an improved technology-based template of lesson plan creation and description;

- to increase the competency of teachers.

The relation of methodological resources with teaching/learning methods should be constructive, on the one hand, and quite flexible on the other hand, therefore it is necessary to use various classification criteria.

\section{A New Model of LO Metadata}

Basing on the analysis of scientific resources and various metadata models (Section 2) for digital resources and study results and formulated Assumptions 1-6 (Section 3), this paper provides an extended LO metadata model, which is aimed not only to describe content learning objects, but also to reflect the peculiarities of methodological resources and learning methods and include their descriptions into the same learning resource repository. As we have already mentioned, the flexibility of the IEEE LOM model allows us to develop new application profiles and there are quite a lot of educational application profiles developed.

In new application profiles, the mandatory and freely chosen elements of metadata are defined, controlled vocabularies and taxonomies are used. The main scientific principles for the development of LO metadata standards and their application profiles are described in Duval et al. (2002). These principles are proposed by the two metadata initiatives: the Dublin Core Metadata Initiative (DCMI) and the Institute for Electrical and Electronics Engineers (IEEE) Learning Object Metadata (LOM) Working Group and include (a) modularity, (b) extensibility, (c) refinement, and (d) multilingualism. Practical principles of metadata development are also provided (application profiles, syntax and semantics, association models, identifying and naming metadata elements, metadata registries, completeness of description, mandatory and optional elements, subjective and objective metadata, and automatic generation of metadata).

The proposed model is based on the LOM LRE v.3 application profile (European Schoolnet, 2011).

Using the classification of MR (Fig. 2) and basing on the analysis of LO models, we present a diagram of LO classes (Fig. 8). Teaching planning resources can be split into two groups: lesson plans and objects founded by the interaction of activities.

When describing LOs, we have to ensure the interoperability not only of different standards, but also of controlled vocabularies used (Kurilovas and Kubilinskienè, 2008). 


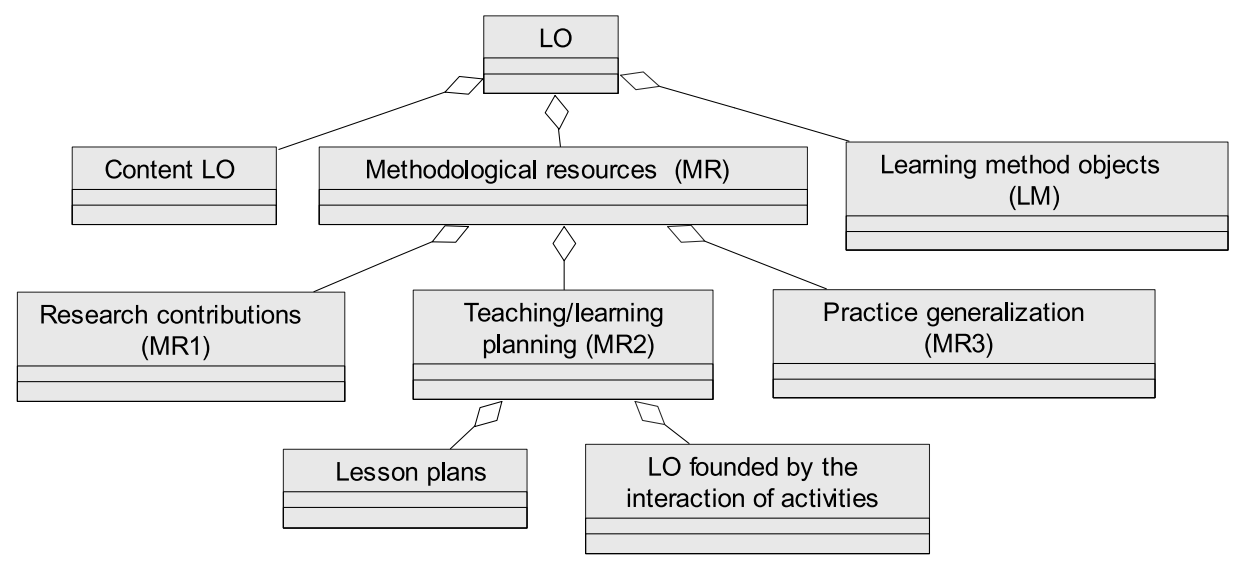

Fig. 8. LO classes.

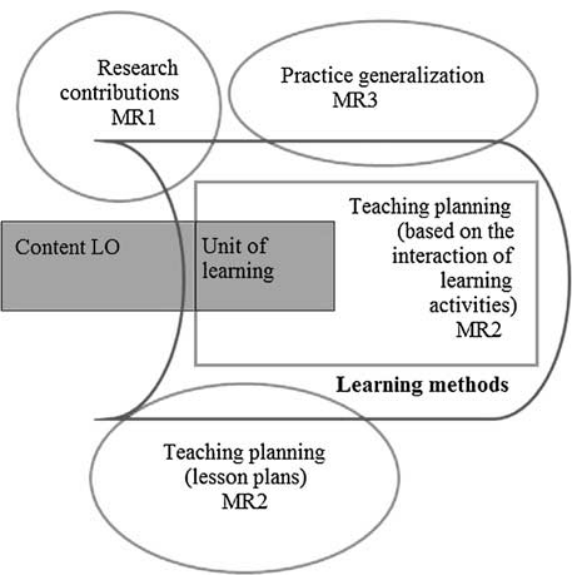

Fig. 9. The scheme of LO semantic relationship.

One of the best ways of semantic interoperability problem solving is composition of multilingual controlled vocabularies (terms and their definitions, context), of multilingual thesauri and ontologies (Kurilovas, 2009).

Figure 9 presents a scheme of LO semantic relationship. LOs, based on specifications and standards are presented in rectangles: there are content LOs and teaching planning resources, based on learning activities. The latter rely on IMS LD specification and make up units of learning, using a certain content specification. LOs created in the natural language are presented in ovals: research contributions (MR1) (e.g., methodological papers, surveys, and methodological conference proceedings), practice generalization resources (MR3) (teacher reflections and opinions, additional educational materials, and use of teaching/learning methods), and teaching planning resources (MR2) as lesson plans. The learning methods are also described in the natural language, as seen from the scheme, they comprise a certain part of each LO class. 


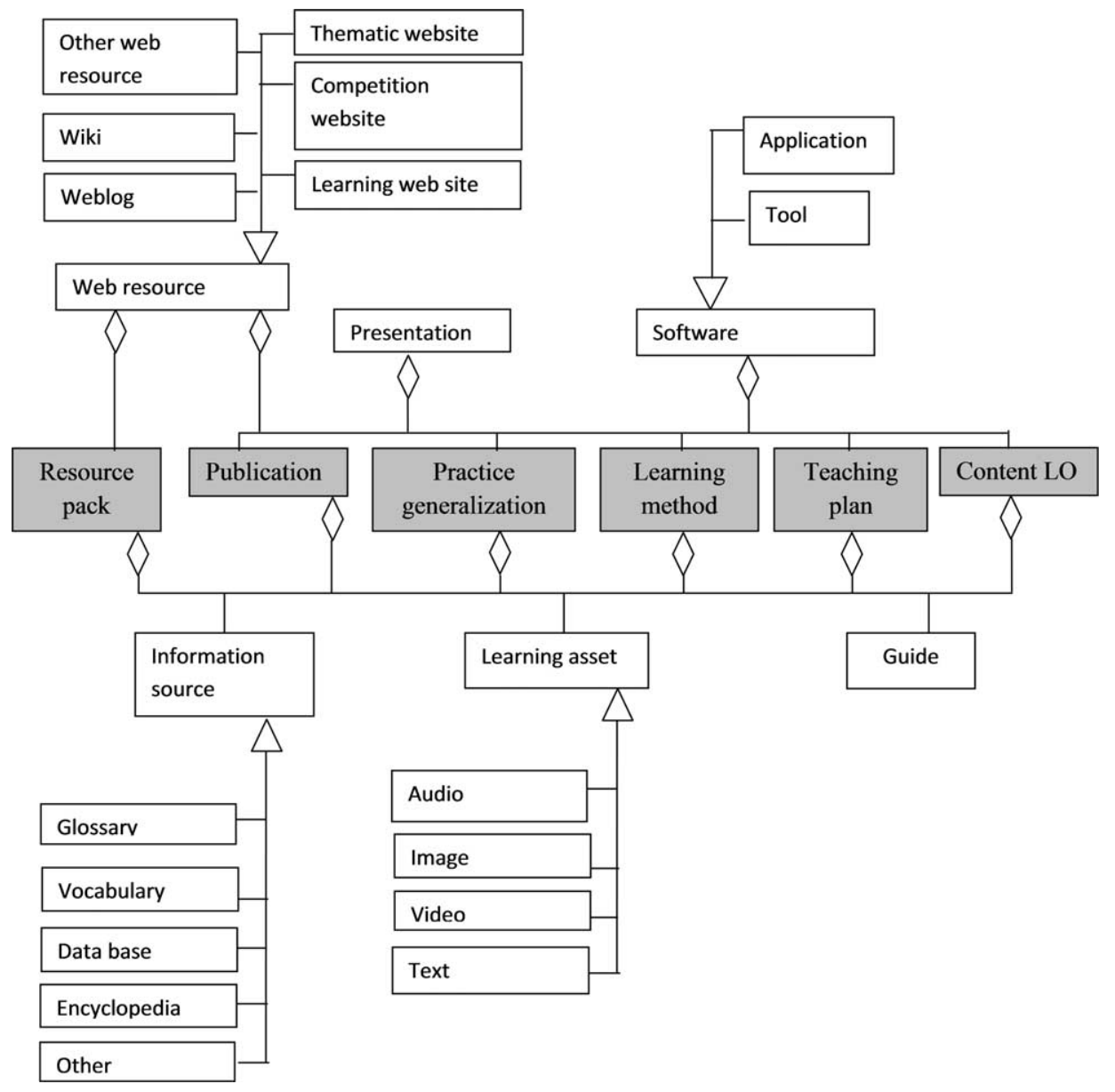

Fig. 10. Learning resource type classification, based on the LRE Learning resource type controlled vocabulary.

Developers of metadata models are recommended to publish their vocabularies in the registry which would allow us to facilitate semantic interoperability and to avoid duplication (Van Assche et al., 2003). The comparative analysis of learning resource type vocabularies, used in the largest European projects, registered in the CEN/ISSS Application Profile Registry system and in the Vocabulary bank for Education has shown that the Lithuanian LO metadata repository search system needs a Learning resource type controlled vocabulary of the LOM standard educational part 5.2 element improved and adopted to education in Lithuania.

The classification of learning resource types is to be understood as the aggregate of LO classes and circumstances (Fig. 10).

The diagram demonstrates that all entities of the marked LO classes can be comprised of learning components, they can use information sources and have a user's guide. The latter exist independently of the marked LO class entities. On the other hand, the marked 


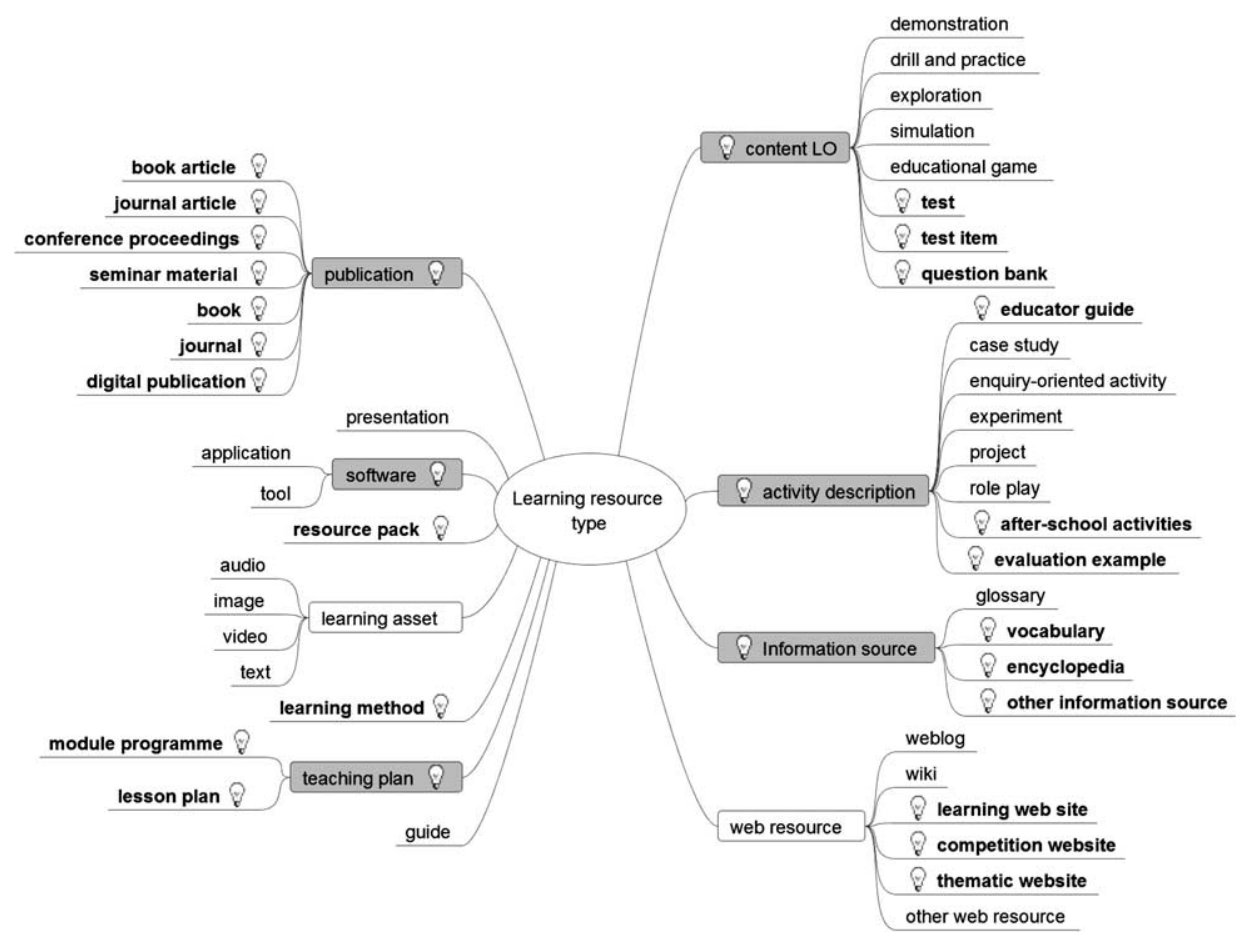

Fig. 11. A set of meanings of Learning resource types controlled vocabulary.

LO class entities can be created and presented as internet resources or presentation. Software tools or applications were used to create them. Thus, according to this classification, each $\mathrm{LO}$ can be easily attributed to one or more elements.

Basing on the learning resource type classification (Fig. 10), we present an improved and extended set of meanings of the LRE Learning resource type controlled vocabulary (Fig. 11).

The branches in this diagram express a learning resource type, and the oval shows the learning resource category. Categories and types of the LRE learning resource type controlled vocabulary are presented in unmarked branches and ovals, and improvement suggestions are represented in "bulb" and bold marked branches and ovals.

Extended controlled vocabulary (LRE Learning Resource Type) lets us to include new resource types: methodological resources and learning methods. New types of LOs (as an addition to existing ones) include:

- publication (book article, journal article, conference proceedings, workshop materials, book, journal, digital publication),

- activity description (educator guide, after-school activity, assessment example),

- information source (dictionary, encyclopedia, other informational resource),

- web resource (educational website, Olympiad or contest website, thematic website), 
- learning or teaching plan (programme, module, chapter plan, lesson or sequence of lessons plan),

- learning method.

\subsection{Proposal of a Learning Method Type Controlled Vocabulary}

To describe learning methods, a new controlled vocabulary has been created. As we know, the single classification that can address all learning and teaching methods in the best way does not exist. We could see from our study (Section 3) that some methods are more often used by teachers than others. To help teachers to learn about various learning and teaching methods and to make their description as flexible as possible, in our proposed new controlled vocabulary, classification by two criteria is used: by the phases of learning process and by student activity (Petty, 2006; Fig. 12). In this way the relation between the methodological resources, content LO and learning methods are defined in a more flexible way.

The vocabulary does not cover all the students' activity types available, so only learning methods of the greatest effect are distinguished (Petty, 2006). Many learning methods can be attributed not only to one type of students' activities, which expands the search result a great deal (Camilleri, 2012). The extended search becomes inefficient and the search result can hardly comply with teachers' expectations.

On the basis of the study results, teachers use classifications of various learning methods, therefore the new learning method type controlled vocabulary has to embrace various classification criteria with a view to increase its flexibility (Fig. 12).

Based on the controlled vocabulary, every method can easily be assigned to some learning phase. Thus, using the controlled vocabulary, each learning method can be attached at least to one element according to two criteria: the learning process phase and students' activity.

\subsection{Importance of LO Relationships for LO Reuse}

It is known from practice that during the creation and description of methodological resources teachers can: (1) describe or relate MR with the learning method, (2) associate it with content $\mathrm{LO}$ used in the learning process.

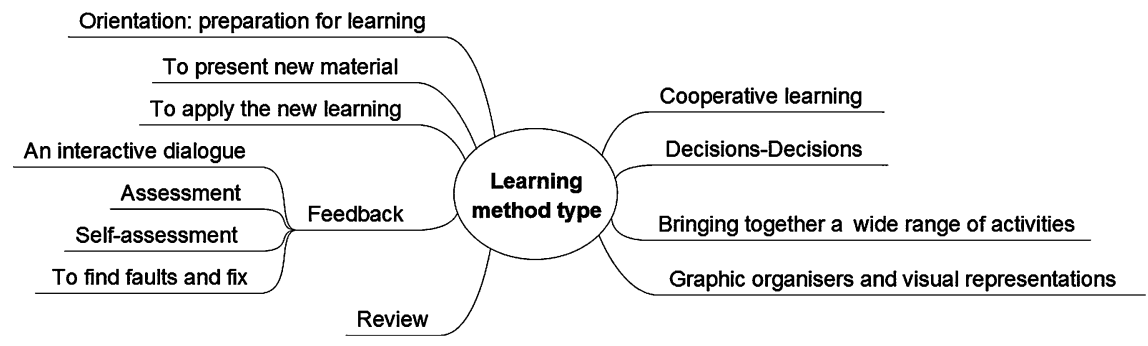

Fig. 12. A set of meanings of the Learning method type controlled vocabulary. 
Table 2

Expansion of meanings of the LRE Relationship Kinds controlled vocabulary

\begin{tabular}{ll}
\hline Meaning & $\begin{array}{l}\text { Notation of meanings in LRE } \\
\text { Relationship Kinds controlled vocabulary }\end{array}$ \\
\hline Use content learning object & Isrequiredby \\
Link to teachers good practice & Requires \\
Use learning method & Isbasedon \\
Example of using learning method & Isbasisfor \\
\hline
\end{tabular}

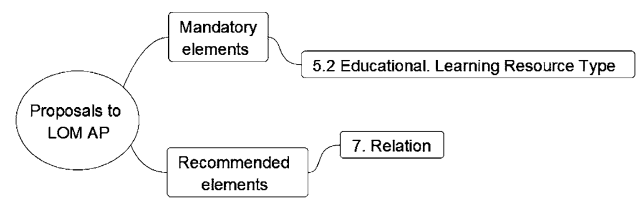

Fig. 13. Offer to change the status of fields.

However, it is impossible to define objects of good experience during the creation or description of content LOs and learning methods, because there are none of them until the latter objects come into being. That can be the reason of low use of content LOs and modern learning methods. The results of empiric research have corroborated this fact.

Automatic backward relations determination solves the problem. In order that automatic backward relation determination will be appropriate and effective, the type of relations must have an unequivocal meaning.

The controlled vocabulary LOM Relationship Kinds has been extended to include bidirectional links between content learning objects, methodological resources, and learning methods. The expanded items of the vocabulary include: use content learning object, link to teachers good practice, use learning method, example of using learning method (Table 2).

These unique values, when showing the LO description in learning resources repository, will provide links to other LOs by topics, i.e., Relationship Kinds.

\subsection{Extended Metadata Model}

The results of empiric research have corroborated the hypothesis that the lack of learning method descriptions, generalized pedagogical practice, as well as lack of lesson or topic plans and lack of methodological recommendations has influence on the use of content learning objects.

In order to improve the searching or browsing opportunities, when looking for methodological resources, content LOs and learning methods, it would be reasonable to change the status of some fields (see Fig. 13).

The change of the status of these elements, its tightening would increase a probability to find related objects of different types more rapidly and accurately. 
Table 3

The elements of LOM extension

\begin{tabular}{|c|c|c|c|c|c|}
\hline $\begin{array}{l}\text { No of } \\
\text { element }\end{array}$ & $\begin{array}{l}\text { Category } \\
\text { title }\end{array}$ & $\begin{array}{l}\text { Element } \\
\text { title }\end{array}$ & Multiplicity & Data type & $\begin{array}{l}\text { Reason for change or } \\
\text { development }\end{array}$ \\
\hline 5.2 & Educational & $\begin{array}{l}\text { Learning } \\
\text { Resource } \\
\text { Type }\end{array}$ & $0 . . *(10)$ & $\begin{array}{l}\text { Extended } \\
\text { controlled } \\
\text { vocabulary (LRE } \\
\text { Learning } \\
\text { Resource Type) }\end{array}$ & $\begin{array}{l}\text { Enables the reference to the } \\
\text { "Learning object type" } \\
\text { classification system }\end{array}$ \\
\hline 9.1 & Classification & Purpose & 1 & $\begin{array}{l}\text { Extended } \\
\text { controlled } \\
\text { vocabulary (LOM } \\
\text { Classification } \\
\text { Purpose) }\end{array}$ & $\begin{array}{l}\text { Enables the reference to } \\
\text { "Learning method type", } \\
\text { "Scope", and "UDC" } \\
\text { classification systems }\end{array}$ \\
\hline 9.2 .2 .1 & Classification & Id & $0 . . *(10)$ & $\begin{array}{l}\text { New controlled } \\
\text { vocabulary } \\
\text { (Learning } \\
\text { method type) }\end{array}$ & $\begin{array}{l}\text { Allows us to indicate the } \\
\text { number of ID value of the } \\
\text { "Learning methods" } \\
\text { vocabulary }\end{array}$ \\
\hline 9.2.2.2 & Classification & Entry & $0 . . *(10)$ & $\begin{array}{l}\text { New controlled } \\
\text { vocabulary } \\
\text { (Learning } \\
\text { method type) }\end{array}$ & $\begin{array}{l}\text { Allows the reference to the } \\
\text { learning methods used and } \\
\text { an expanded search for } \\
\text { content LO, learning } \\
\text { methods, or methodological } \\
\text { material of a selected } \\
\text { learning method }\end{array}$ \\
\hline 9.2.2.1 & Classification & Id & $0 . . *(10)$ & $\begin{array}{l}\text { New controlled } \\
\text { vocabulary } \\
\text { (Scope) }\end{array}$ & $\begin{array}{l}\text { Enables to indicate the } \\
\text { number of ID value of the } \\
\text { "Scope" vocabulary }\end{array}$ \\
\hline 9.2.2.2 & Classification & Entry & $0 . . *(10)$ & $\begin{array}{l}\text { New controlled } \\
\text { vocabulary } \\
\text { (Scope) }\end{array}$ & $\begin{array}{l}\text { Allows to indicate the } \\
\text { number of learners (group } \\
\text { size) the activity is designed } \\
\text { for (e.g., individual activity, } \\
\text { work in pairs, work in } \\
\text { groups, whole-class activity) }\end{array}$ \\
\hline 7.1 & Relation & Kind & $0 . .1$ & $\begin{array}{l}\text { Extended } \\
\text { controlled } \\
\text { vocabulary (LOM } \\
\text { Relationship } \\
\text { Kinds) }\end{array}$ & $\begin{array}{l}\text { Enables to indicate unique } \\
\text { values to establish an } \\
\text { automatic relation between } \\
\text { LOs }\end{array}$ \\
\hline
\end{tabular}

The extended metadata model will enable us to perform the following LO regulative functions: data storing, search, technical and functional compatibility using metadata that will correlate the properties of content LO, methodological resources and learning methods objects (bibliographical, educational, technical and digital rights).

Applying the major scientific and practical principles for the development of LO metadata standards and their application profiles, on the base of the LRE LOM AP v.3 model, we propose an extended metadata model of digital learning resources, that allows us to describe content objects, methodological resources and teaching method objects. 


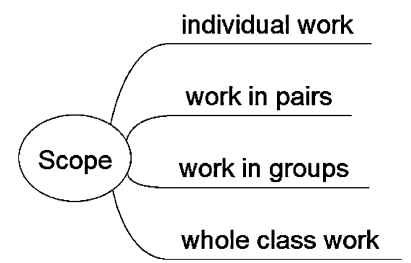

Fig. 14. Meanings of the controlled vocabulary Scope.

The elements in the model are grouped into 9 categories: General, Life Cycle, MetaMetadata, Technical, Educational, Rights, Relation, Annotation and Classification. The elements of LOM extension are presented in Table 3.

Classification category 9 enables us to represent teaching (learning) methods in LO metadata standard. Therefore, we suggest to present a new controlled vocabulary "Learning methods" and to expand Educational category 5 by introducing new elements.

The extended meanings of the LOM Classification Purpose controlled vocabulary are the following:

- learning methods types;

- scope;

- UDC.

As indicated in Table 3, the new controlled vocabulary Scope allows us to describe the intended quantity of learners for the particular activity (meanings are given in Fig. 14).

Information about the scope, presented in metadata, will let users to restrict search of any type of learning resource and make search results more accurate.

\section{Conclusion}

A methodological resource and teaching/learning method description have been distinguished as separate categories of learning objects what enables to consider inclusion LOs of these categories into LO metadata repository.

After considering the metadata standard models LEEE LOM, DC, MARC21 and UNIMARC that can describe methodological resources and teaching/learning method objects, we have concluded that the IEEE LOM model is most suitable to describe the peculiarities of methodological resources and teaching/learning method objects.

A study on the LO usage by the teachers and access from the LO metadata repository has shown that:

1. Not extensive usage of content LOs is influenced by the lack of learning methods descriptions and methodological resources. The teachers prefer to find all these types of LOs in a single place, i.e., the LO metadata repository.

2. Teachers still rarely use so called active teaching/learning methods. The lack of learning methods descriptions and methodological resources of pedagogical practice generalization and their comfortable access can be considered as one of the causes of this. 
3. There is dependence between LOs usage and educators' competencies.

4. In LO metadata repository, there are not enough links between methodological resources and learning methods, as well as content LOs and appropriate methodological resources. The implementation of these links can improve the LO search efficiency and accuracy.

The study has helped to find directions for metadata model of digital learning resources development.

Basing on the LO metadata standard application profile enhancement scientific principles we propose an extended digital learning resource metadata model on the basis of the LRE LOM AP v.3.0. The main properties of the model proposed are as follows:

1. A possibility for structural description of content objects, methodological resources and learning method objects has been designed.

2. The means to automatically implement a backward LO relation have been created which enables us to present the relationship of $\mathrm{LO}$ with other LOs by topics.

The expanded model proposed here differs from the LRE LOM AP v.3 model in that it has improved and extended the meanings of 3 controlled vocabularies and proposed 2 new controlled vocabularies.

\section{References}

Barbosa, E.F., Maldonado, J.C., Ricarte, I.L.M. (2003). Exploring learning objects under conceptual, instructional and didactic perspectives. In: Melo, R.N., de Souza e Silva, D., Siqueira, S.W.M. (Eds.), Proceedings of the I PGL Database Research Conference (PGLDB 2003), pp. 33-39.

Camilleri, P. (2012). Teacher's interpretations of the internet. A applied case study for the evaluation of technological frames of reference. Informatics in Education, 11(2), 151-168.

Duval, E., Hodgins, W., Sutton, S., Weibel, S.L. (2002). Metadata principles and practicalities. D-lib Magazine, 8(4), 1-16.

European Schoolnet (2011). The EUN learning resource exchange lom application profile. http: / / fire. eun. org/node/ 6 [accessed on 2012-11-08].

McClelland, M. (2003). Metadata standards for educational resources. IEEE Journal on Computer, 36(11), $107-109$.

IEEE Standard for Learning Object Metadata (2002). 1484.12.1-2002.

http: / / ieeexplore. ieee. org/servlet / opac ? punumber=8032 [accessed on 2012-11-08].

Kubilinskienè, S., Dagienè, V. (2010). Technology-based lesson plans: preparation and description. Informatics in Education, 10(2), 217-228.

Kubilinskienè, S., Kurilovas, E. (2008). Lithuanian learning objects technical evaluation tool and its application in learning object metadata repository. In: Informatics Education Contributing Across the Curriculum: Proceedings of the 3rd International Conference "Informatics in Secondary Schools - Evolution and Perspective" (ISSEP-2008), Torun, Poland, pp. 147-158.

Kurilovas, E. (2009). Learning objects reusability and their adaptation for blended learning. In: Proceedings of the 5th International Conference on Networking and Services (ICNS 2009), Valencia, Spain, pp. 542-547.

Kurilovas, E., Kubilinskienė, S. (2008). Analysis of Lithuanian LOM repository strategies, standards and interoperability. In: Proceedings of the 2nd International Workshop on Search and Exchange of e-Learning Materials (SE@M'08) within the 3rd European Conference on Technology Enhanced Learning (EC-TEL'O8), Vol. 385, Maastricht, Netherlands.

Petty, G. (2006). Evidence Based Teaching: A Practical Approach. Nelson Thornes, Cheltenham.

Steinacker, A., Ghavam, A., Steinmetz, R. (2001). Metadata standards for web-based resources. IEEE Journal on Multimedia, 8(1), 70-76.

Turcsanyi-Szabo, M. (2012). Aiming at sustainable innovation in teacher education - from theory to practice. Informatics in Education, 11(1), 115-130. 
Van Assche, F., Campbell, L.M., Rifon, L.A., Willem, M. (2003). Semantic interoperability: use of vocabularies with learning object metadata. In: Proceedings of the 3rd IEEE International Conference on Advanced Learning Technologies, pp. 511-514.

Wiley, D. (2000). Connecting Learning Objects to Instructional design Theory: A Definition, a Metaphor, and a Taxonomy. Utah State University.

V. Dagienè is professor and head of the Department of Informatics Methodology at Vilnius University Institute of Mathematics and Informatics. She has published over $100 \mathrm{sci}-$ entific papers and the same number of methodological works, has written more than 50 textbooks in the field of informatics and ICT for high schools. She has been working in various expert groups and work groups, organizing the Olympiads in Informatics among students, also engaged in localization of software and educational programs, e-learning, and problem solving. She is an executive editor of international journals "Informatics in Education" and "Olympiads in Informatics".

T. Jevsikova, $\mathrm{PhD}$ in computer science is a researcher in the Department of Informatics Methodology at Vilnius University Institute of Mathematics and Informatics, as well as a lecturer at the Department of Mathematics and Informatics at Vilnius University. Her main research interests include software localization, cultural aspects of human-computer interaction, e-learning, and standards. She is the author (or a co-author) of 20 scientific papers, several methodological books and glossaries of computer science terms. She is a junior member of the IFIP Group on Informatics in Secondary Education (WG 3.1).

S. Kubilinskienė received her $\mathrm{PhD}$ in informatics engineering from the Vilnius University Institute of Mathematics and Informatics. Her research interests include the management and reuse of digital learning resources, metadata specification and standards, development of learning objects and related software, learning management systems and environments.

\title{
Metodologiniu ištekliu integravimas i mokymosi objektu metaduomenų saugyklą
}

\author{
Valentina DAGIENĖ, Tatjana JEVSIKOVA, Svetlana KUBILINSKIENĖ
}

Skaitmeniniu ištekliu, kurie gali būti taikomi mokymui(si) ivvairiuose kontekstuose (vadinamuju mokymosi objektu), kiekis nuolat didèja, todẻl mokymosi objektu aprašymas metaduomenimis yra svarbus ir aktualus norint pagerinti mokymosi objektu struktūrinima, paiešką ir naudojimą. Mokymosi objektai gali būti nagrinejjami ne tik kaip ištekliai, tiesiogiai teikiantys mokomajị turinị, bet taip pat kaip metodinè medžiaga (pvz., pedagogu patirties aprašymai, refleksija, turinio mokymosi objektų naudojimo klaseje pavyzdžiai) ir mokymo(si) metodų aprašai. Tačiau egzistuojantys standartai ir specifikacijos mokymosi objektų metaduomenims aprašyti nèra skirti metodiniams ištekliams. Šiame straipsnyje pateikiami tyrimo, atlikto dalyvaujant bendrojo lavinimo mokyklos mokytojams, rezultatai, kurie padeda išsiaiškinti pedagogų nuomonę apie metodologinių mokymosi objektų reikalingumą. Remiantis šio tyrimo rezultatais ir metaduomenu taikomujų modeliu projektavimo moksliniais ir praktiniais principais siūlomas naujas mokymosi objektų metaduomenu modelis, kuris leidžia aprašyti metaduomenimis metodologinius išteklius, mokymosi metodų aprašus ir apibrèžti jų ryšius su turinio objektais. 